\title{
Distribution of CBCT-3D examination referrals at Dental Hospital Universitas Airlangga
}

\author{
Eha Renwi Astuti”* (iD), Deny Saputra', Aga Satria Nurrachman' (iD, \\ Dina Karimah Putri', Ratu Sofia Nur Aini ${ }^{2}$, Umi Lutfiah ${ }^{2}$
}

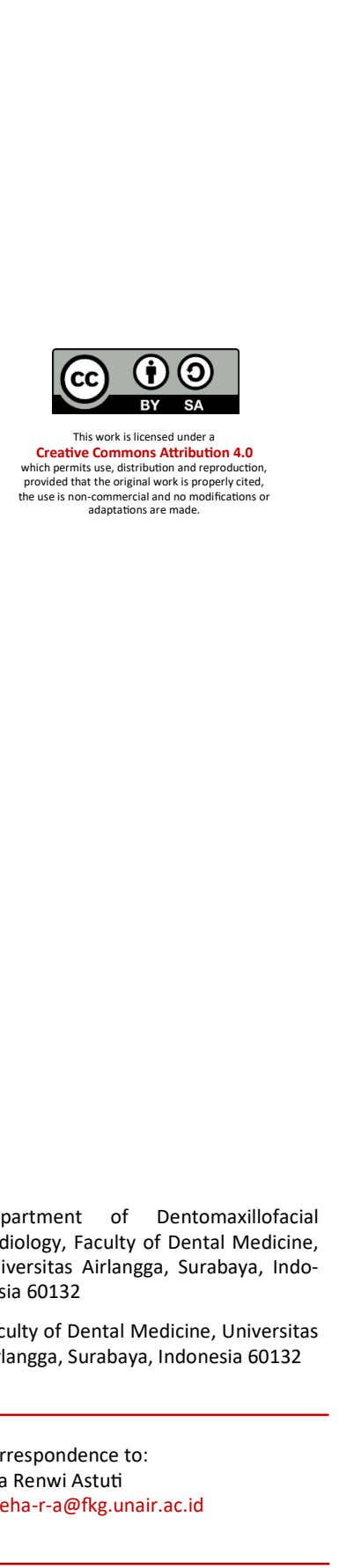

Received on: November 2021 Revised on: December 2021 Accepted on: December 2021

\section{ABSTRACT}

Objectives: This study aims to find out the distribution of CBCT-3D examination referrals at Dental Hospital Universitas Airlangga based on the origin of referral, specialist field, age and gender.

Materials and Methods: This descriptive research is using the total sampling method. Secondary data from the medical records of any referral patients for CBCT-3D examination at Dental Hospital Universitas Airlangga from July 2015 to March 2020 were included in this study. Furthermore, data references were tabulated and presented in the form of a pie chart.

Results: The distribution of CBCT-3D examination referrals at Dental Hospital Universitas Airlangga was as high as 323 (77.64\%) coming from within the hospital and as much as 93 (22.36\%) from outside of the hospital. Based on the dental specialties who made the referral, six of seven departments have referred their patients for CBCT examination with varying proportions and indications. The distribution of referrals was also divided into gender (male or female) and several age categories based on the Indonesian Ministry of Health, such as toddlers (ages 0-5 years), children (ages 5-11 years), adolescents (ages 12-25 years), adults (ages 26-45 years), elderly (ages 46-65 years) and seniors (over 65 years).

Conclusion: Referrals for CBCT-3D radiography examinations at Dental Hospital Universitas Airlangga are mostly from within the hospital, from the Department of Oral and Maxillofacial Surgery. Female and elderly patients (46 years and older) were found to be the most frequently referred.
Keywords: $C B C T$ referral, distribution, $C B C T$, radiography, health service

Cite this article: Astuti ER, Saputra D, Nurrachman AS, Putri DK, Aini RSN, Lutfiah U. Distribution of CBCT-3D examination referrals at Dental Hospital Universitas Airlangga. Jurnal Radiologi Dentomaksilofasial Indonesia 2021;5(3)100-5. https://doi.org/10.32793/jrdi.v5i3.743

\section{INTRODUCTION}

A dental and oral hospital is a facility that two-dimensional image to a three-dimensional provides dental and oral health services for image commonly referred to as Cone Beam recovery, treatment, prevention, and referral for Computed Tomography Three-Dimension (CBCTdental and oral diseases. As a referral center, the $3 D$ ) examination. CBCT-3D is an extraoral imaging dental hospital is obliged to accept the technology that is able to answer the limitations of responsibility for a case of disease. ${ }^{1}$ Quoted from 2-dimensional radiography. This technology allows the Decree of the Director of Dental Hospital three-dimensional imaging of images, producing Universitas Airlangga 496 / UN3.9.3 / OT / 2016, ${ }^{2}$ more accurate and detailed results. CBCT-3D is according to the relationship, the referral system is particularly beneficial for a variety of specialist divided into internal and external referrals. While areas in dentistry. According to Alshehri et al. ${ }^{3}$, the type of referral based on the scope of service which collected 129 literatures on the use of CBCTconsists of health referrals and medical referrals. 3D in various dentistry practices, the distribution of Medical referrals available at Dental Hospital CBCT-3D utilization is produced as follows: Oral and Universitas Airlangga consists of various services Maxillofacial Surgery as much as $26.3 \%$, including outpatient, inpatient, medical action Endodontics as much as $25.6 \%$, Implants $16.3 \%$, services and diagnostic services such as Orthodontics as much as $11.6 \%$, General dentistry radiography.

Radiographic examination becomes one of the most references because the imaging results can assist practitioners in determining diagnoses, establishing treatment plans and evaluating the outcomes of treatments that have been performed. Today, radiography examination has evolved from a as much as $9.3 \%$, Temporomandibular joint $5.4 \%$, Periodontics $4.65 \%$, and Forensic Odontology $0.8 \%$. Hidayanti ${ }^{4}$ on the use of CBCT-3D examination in referral cases at Dental Hospital Universitas Padjajaran, obtained distribution results namely Orthodontics $(28,6 \%)$, Pedodontics $(28,6 \%)$, ER $(14,3 \%)$, Rontgen $(14,3 \%)$, Cleft Center $(14,3 \%)$, 
Surgery (0\%), Prosthodontic (0\%), and Conservative Dentistry (0\%).

Referrals for CBCT-3D examinations in various dental specialties are inextricably linked to the benefits possessed. The advantages of CBCT include its high level of accuracy, which allows it to display images of objects from three orthogonal fields, namely sagittal, axial, and coronal, reducing the risk of practitioner misinterpretation. Furthermore, the CBCT-3D inspection data collection process is typically faster, lasting about 1 minute or less depending on the type of unit. CBCT-3D also has a field of view (FOV) option that can be adjusted to the examination indication to focus the area of interest (ROI) and prevent excess radiation in the surrounding area. This feature also contributes to the relatively high resolution of the CBCT-3D examination results. ${ }^{6}$

Not only beneficial for practitioners in various dental specialties, CBCT-3D examination is usefu for examining patients in various sociodemographic that include age, gender, occupation, religion, economic status, and so on. ${ }^{7}$ There is an influence on the patient's age and gender differences on CBCT-3D examination services. According to AlNajjar et $a l^{7}$, pediatric and adult patients have different levels of radiation absorption when given the same radiation exposure. Because pediatric patients are more likely to absorb more radiation, there must be a different exposure arrangement of radiation doses in CBCT-3D examination services. The appearance of motion artifacts during CBCT-3D examination was also observed in elderly patients (over 60 years), children (under 15 years), and female patients who experienced anxiety. ${ }^{8,9}$ As a result, there must be a proper standard operating procedure and mechanism in place in the CBCT-3D service to prevent the final result of images from failing. The radiographic failure will result the examination to get repeated and an increase in the amount of radiation received by the patient.

The goal of this study is to determine the distribution of CBCT-3D examination referrals at Universitas Airlangga Dental Hospital based on the source of referral, specialist field, gender, and age. It is critical to do so in order to improve CBCT-3D services and accuracy in radiology department.
Despite the fact that CBCT-3D examination is frequently referred by practitioners, similar research topics are still uncommon. CBCT-3D examination services have been available at Dental Hospital Universitas Airlangga since 2015. However, there is currently no distribution data that can be used as a reference to improve service for radiographic examination. This study is expected to provide data on the distribution of CBCT-3D referrals as supporting examinations in the field of dentistry, as well as evaluation materials to improve CBCT-3D examination services at the Dental Hospital Universitas Airlangga.

\section{MATERIALS AND METHODS}

This research has received approval from the Health Research Ethics Commission (KKEPK) of the Faculty of Dentistry, Universitas Airlangga. This research was held in July 2021 to September 2021 at Dental Hospital Universitas Airlangga.

This study employs a descriptive design to picture the referral of CBCT-3D examination at Dental Hospital Universitas Airlangga based on the source of the referral, specialist field, gender, and age. This study's population is derived from medical records of reference requests for CBCT-3D radiography examinations collected using the total sampling method, which included 482 reference data. The sample used in this study was CBCT-3D referrals taken from July 2015 to March 2020, referred by a dentist or specialist at Dental Hospital Universitas Airlangga, have complete data related to age, gender, and supporting data in accordance with the purpose of the referral. The data is then tabulated and presented in the form of a pie chart.

\section{RESULTS}

The study obtained as many as 416 CBCT-3D radiographic examination reference data that met the criteria, with 323 referrals $(77,64 \%)$ coming from internal Dental Hospital Universitas Airlangga and 93 referrals $(22,36 \%)$ from the external or outside of the hospital as shown in Figure 1.

\section{Referrals Based on The Origin of The Referral}

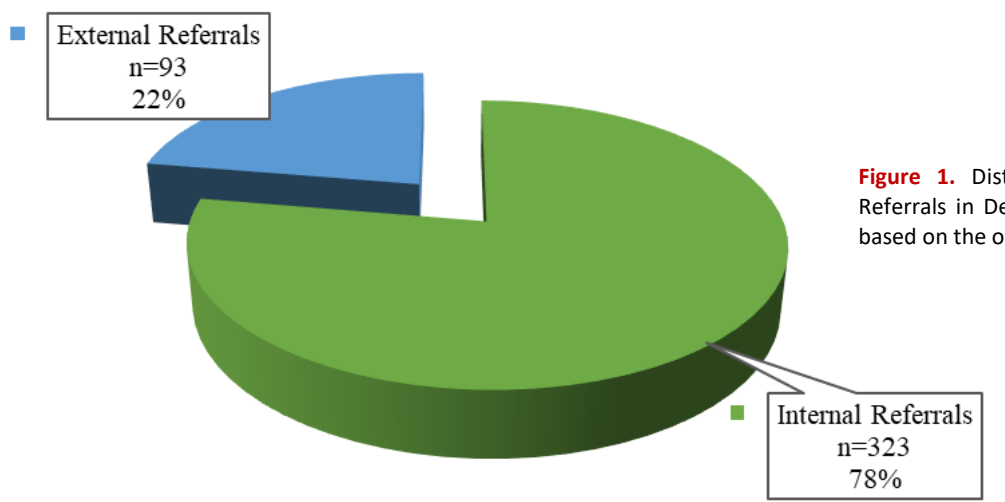




\section{ORIGINAL RESEARCH ARTICLE}

The distribution of CBCT-3D examination referrals based on the referring dental specialties can be seen in Figure 2. Sequentially, the largest referral distribution came from Oral and Maxillofacial Surgery at 166 referrals $(39,90 \%)$, Periodontics 109 referrals $(26,20 \%)$, Conservative Dentistry 60 referrals $(14,43 \%)$, Prosthodontics 43 referrals $(10,34 \%)$, Orthodontics 31 referrals $(7,45 \%)$, Pediatric Dentistry 7 referrals $(1,68 \%)$, and Oral Medicine (0\%).
Figure 3 describes the distribution of CBCT-3D examination referrals based on age categorized according to the Ministry of Health of the Republic of Indonesia in 2009. The results showed that the distribution of referrals in toddlers (ages $0-5$ years) as much as $0(0 \%)$, children (ages $5-11$ years) by 8 (1.92 years), adolescents (ages $12-25$ years) by 124 (29.81\%), adults (ages 26-45 years) as many as 128 (30.77 years), elderly (age 46 - over 65 years) with a total referral of $156(37.50 \%)$.

\section{Referral Based on Dental Specialties}

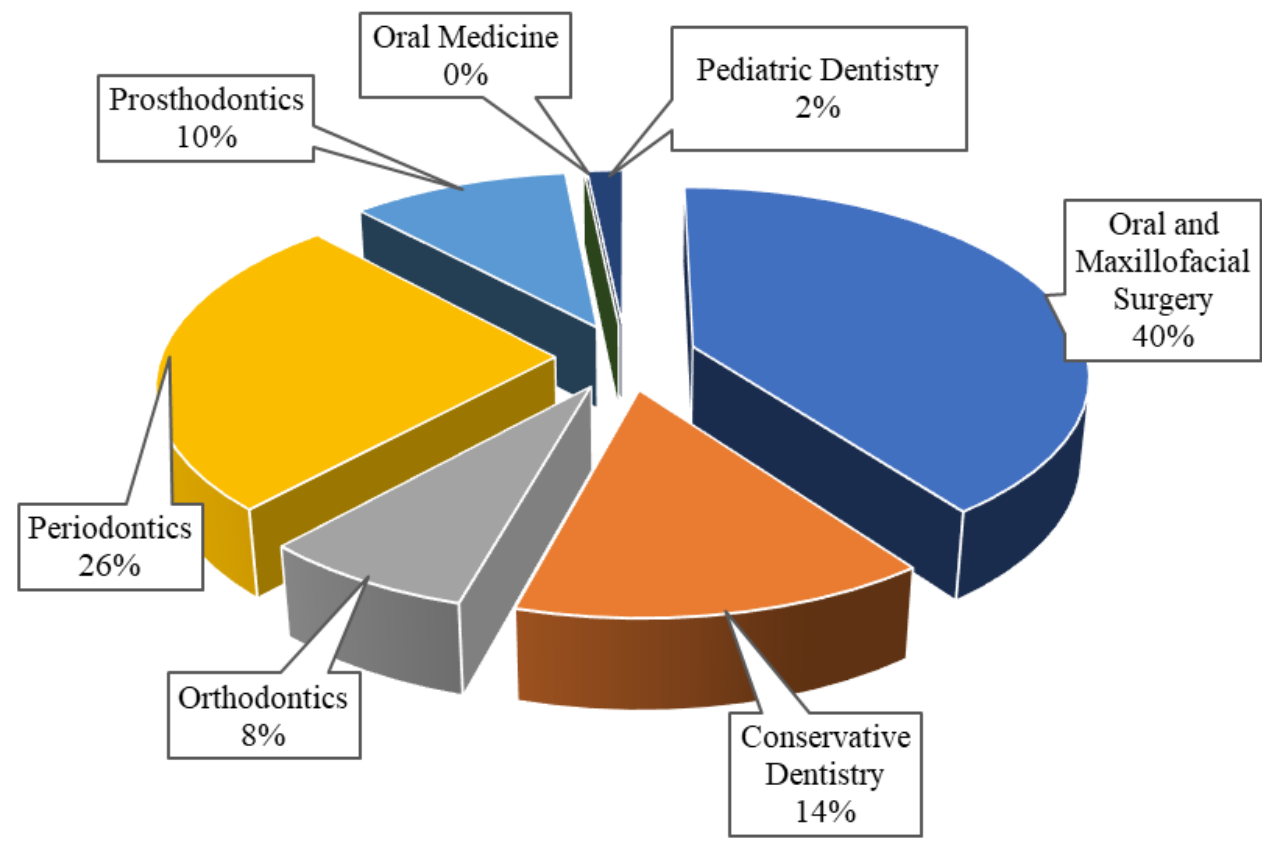

Figure 2. Distribution of CBCT-3D Examination Referrals in Dental Hospital Universitas Airlangga based on specialty field of Dentistry

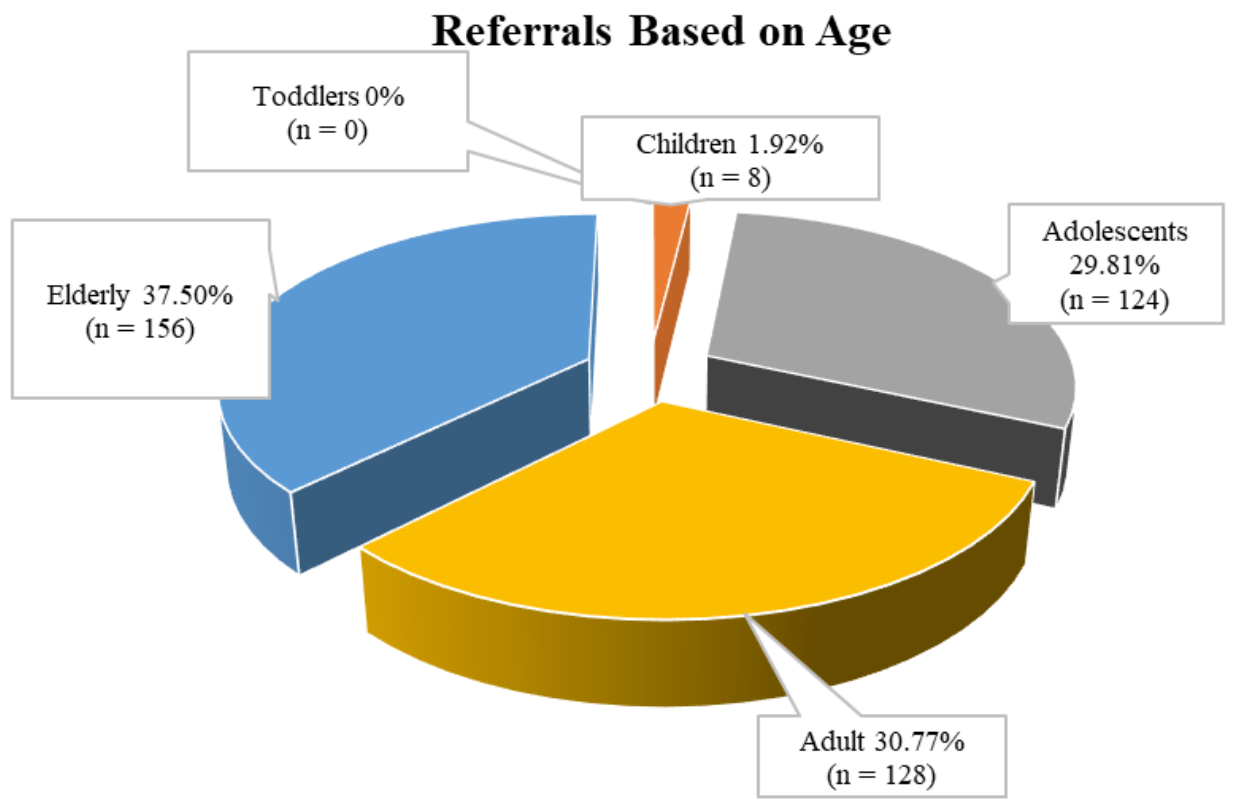




\section{Referrals Based on Gender}

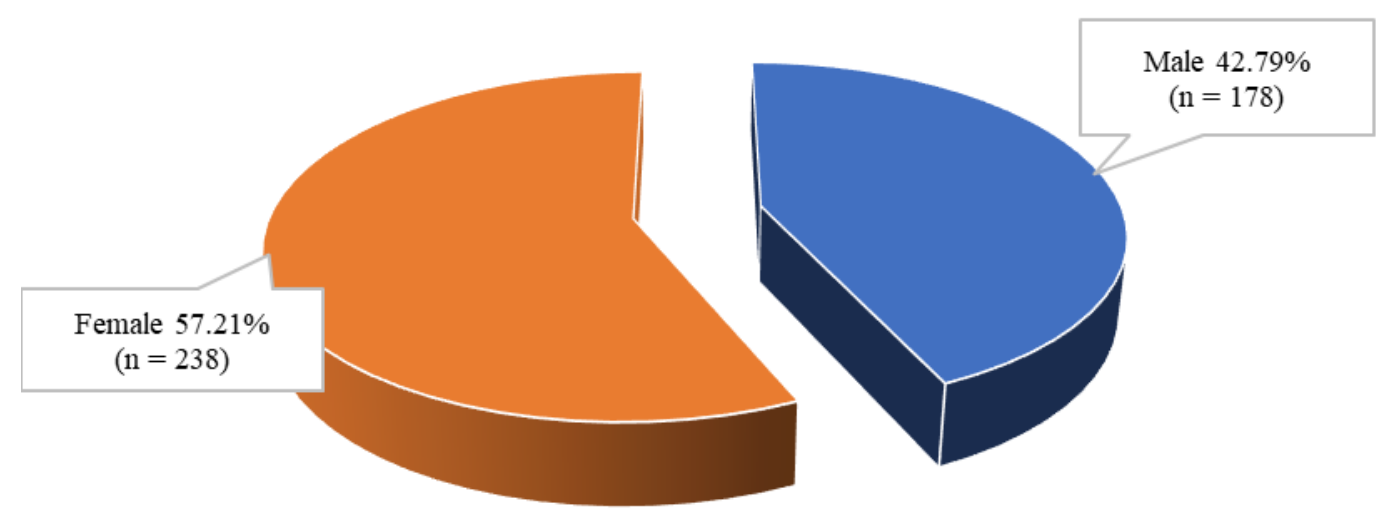

Figure 4. Distribution of CBCT-3D Examination Referrals in Dental Hospital Universitas Airlangga based on gender

The distribution of CBCT-3D examination referrals based on gender can be seen in figure 4. The results showed that female patients were referred more than male patients. The distribution of referrals to female patients amounted to 238 data (57.21\%) and male patients by 178 data (42.79\%).

\section{DISCUSSION}

Based on the study's findings, 482 data were obtained, representing the total reference data of CBCT examinations performed at Dental Hospital Universitas Airlangga from July 2015 to March 2020. There were 416 data that have complete information of patient's backgrounds to meet the criteria of research samples, both internal and external, out of the total data. Figure 1 shows that internal patient referral data outnumbered external Dental Hospital Universitas Airlangga referrals. This is due to the fact that Dental Hospital Universitas Airlangga serves as the primary teaching hospital for the Dental Specialist Education Program (PPDGS) Faculty of Dental Medicine of Universitas Airlangga. The requirement that the Faculty of Dentistry, which organizes Dental Specialist Education Program, must have educational facilities in the form of dental hospital as the primary educational implementation vehicle to support education programs in accordance with education standards passed by the Indonesian Medical Council (KKI). ${ }^{10}$ In addition, in accordance with the qualification level of $8 \mathrm{KKNI}$, a specialist in the field of dentistry must be able to develop knowledge, technology, and / or art in the field of science or professional practice through research to produce innovative and tested works ${ }^{11}$, including the use of CBCT-3D technology.

The results of the study on CBCT-3D examination reference data according to the field of specialists (Figure 2), the Oral and Maxillofacial Surgery has the most referral distribution of
$39,90 \%$. The purpose of CBCT-3D use in the field of oral and maxillofacial surgery varies, among others, to determine the location, process of the course of the disease, relationship with vital structures in some cases of diseases such as cleft lip and palate, tooth and jaw fractures, tooth impaction, supernumerary teeth and others. ${ }^{3}$ The periodontics field occupies the second most CBCT-3D inspection referral frequency with a percentage of $24,7 \%$. Radiographic examination of the field of periodontics is usually associated with bone observation to measure bone thickness defects, bone recession and bone density. 2D intraoral radiography is an imaging commonly used in looking at bone morphology and bone defects. However, due to dimensional limitations, it frequently leads to misinterpretation of the number of bones lost or still available. CBCT-3D is the answer to these limitations with 3 orthogonal planes, namely sagittal, coronal and axial, allowing them to see bone defects from different perspectives accurately. ${ }^{3}$

The diversity of cases in both fields, makes practitioners need to understand the use of FOV (field of view) in accordance with the indication of their respective cases. Narrow and limited vision (small FOV) is used to examine localized pathologies such as tooth impaction, implants, some cysts, and supernumerary teeth in oral maxillofacial surgery, as well as the furcation involvement, aperture or lingual defects, infrabony defects and to assess the effects of regenerative therapy on the field of periodontics. While widespread cases such as granulomas, cysts, jaw fractures require a broader view with large FOV. ${ }^{12}$ FOV selection should be adjusted to the indication of the case because it affects the radiation dose caused and the accuracy and resolution of the image. CBCT-3D machine in Dental Hospital Universitas Airlangga offers several FOV options, including $4 \times 4 \mathrm{~cm}, 6 \times 4 \mathrm{~cm}, 6 \times 6 \mathrm{~cm}$, $6 \times 8 \mathrm{~cm}, 8 \times 8 \mathrm{~cm}$ and $11 \times 8 \mathrm{~cm}$.

Oral Medicine is a branch of medicine that uses a non-dissective approach to treat local soft tissue 
disorders. As a result, no CBCT-3D examination reference data were obtained in this study. This can be explained by the CBCT-3D examination's limitations, which include low resolution and poor contrast to the soft tissue image. There are no referrals for CBCT-3D examinations from this field. However, some literature suggests that in some cases of soft tissue calcifications such as tonsiloliths and sialoliths, CBCT-3D examination can be used to determine the location, number, and shape of the calcification as well as relationships with surrounding vital structures. ${ }^{13,14}$

Study on the distribution of referrals by age in this research was categorized according to the age grouping by Ministry of Health of the Republic of Indonesia in 2009, namely: toddlers (ages 0-5 years), children (ages 5-11 years), early adolescents (ages 12-16 years), late adolencents (ages 17-25 years), early adults (ages 26-35 years), late adults (ages 36-45 years), early seniors (ages $46-55$ years), elderly (ages 56-65 years), and seniors (over 65 years). ${ }^{15}$ However, the findings of this study resulted in a classification with the following details: toddlers, children, adolescents, adults, and the elderly, because the merging of age categories is based on characteristics that are not significantly different. According to the findings of this study, the elderly and seniors had the greatest distribution $(37.50 \%)$. The age of the elderly is combined with the age of seniors as both of their characteristics are more or less the same, such as the declines in body function, biological, physical, psychological, psychosocial, mental, cognitive and economic status. ${ }^{16}$ The difference is only in the degree of severity. In addition, there is a renewal of the classification of the elderly according to the Ministry of Health in 2013 which is divided into two, namely the elderly $45-60$ and the elderly 60 years and above. ${ }^{17}$ As a result, the elderly in this study are between the ages of 46 and 65 .

Elderly patients, which account for the majority of referral distribution, must be considered when developing a policy or program for elderly-friendly health facilities at Dental Hospital Universitas Airlangga, including in radiology department. Indicators of elderly-friendly facilities according to WHO in Lativa et $a l^{18}$ are the design of buildings or rooms that are accessible such as adequate lighting, the presence of a walled handle as a buffer for elderly movement and maximize the size of the room. ${ }^{19}$ In addition, it is recommended that elderly patients in CBCT-3D examinations are positioned to sit to minimize movement during the examination. Another indicator of elderly-friendly facilities is the ease of getting information. Seniors need to be given precise information or instructions regarding CBCT-3D examinations. In the elderly with hearing loss, radiographers need to use special techniques of communication such as non-verbal communication, medias e.g. leaflets or videos that are easy to understand..$^{20,21}$ The final indicator is a simple and convenient service. This means that the services provided by operators must be pleasant and caring, and the CBCT-3D services should be easily accessible to any elderly patients with various conditions, such as patients with hunched posture due to osteoporosis and patients in wheelchairs, allowing them to get the most out of CBCT-3D examination services.

The impact of reference frequency on other age groups is measured in terms of radiation doses and motion artifacts. Radiographers in CBCT-3D examination services must understand the differences in radiation doses in different age groups. According to al-Najjar et al. ${ }^{7}$ study, when children and adults are given the same radiation exposure, children have a greater absorption rate of radiation. Furthermore, CBCT-3D services must also minimize the risk of motion artifacts that can occur during the examination. According to Kerris et al. ${ }^{9}$ and Neto et al. $^{22}$, motion artifacts often arise due to movement in patients under the age of 15 and over 60 years old. As a result, the radiographer must minimize motion artifacts by providing clear instructions to the patient, providing head restraints such as a head support and chin cup, and instructing the patient to close his eyes during the examination. $^{23}$

Figure 4 shows that female referral patients were more numerous than male patients with a percentage of female patients of $57.21 \%$ and $42.79 \%$ for male patients. The high frequency of female patients in CBCT-3D examinations can be attributed to the fact that women are more concerned about their appearance including the oral cavity. ${ }^{24}$ Buunk-Werkhoven ${ }^{25}$ also stated that women tend to be more concerned about their oral health than men. According to the research, female patients receive more dental care, follow practitioner recommendations, and have good oral cavity health literacy. Although the frequency of women is higher than Kerris et al. ${ }^{8}$ and Bhagia et $a l^{26}$, female patients have a high enough level of anxiety during examination so that it is more at risk of motion artifacts. The appearance of motion artifacts can be avoided by providing education and clear examination instructions to reduce patient anxiety. ${ }^{27}$

\section{CONCLUSION}

From July 2015 to March 2020, the majority of CBCT-3D radiography examination referrals at Dental Hospital Universitas Airlangga mostly came from practitioners within the hospital. The Department of Oral and Maxillofacial Surgery refers to its patients the most frequently, with female and the elderly age group (46 years and up) receiving the most referrals.

\section{ACKNOWLEDGMENTS}

None.

\section{FOOTNOTES}

All authors have no potential conflict of interest to declare for this article. This research was 
registered and approved by Research Ethics Committee with the registration number of 0718060916. All procedures conducted were in accordance with the ethical standards.

\section{REFERENCES}

1. Ministry of Health Republic Indonesia. Ministerial Decree on Individual Health Service Referral System. 0012012.

2. Decree of the Director of Dental Hospital of Universitas Airlangga. Surabaya: Dental Hospital of Universitas Airlangga; 2016

3. Alshehri MA, Alamri H, Alshalhoub M. Applications of CBCT in Dental Practice: A Literature Review. Dent News. 2011;18:2634.

4. Hidayanti N. Deskripsi Pemanfaatan, Distribusi, dan Rujukan Radiografi Cone Beam Computed Tomography. 2013.

5. Adibi S, Zhang W, Servos T, O'Neill PN. Cone Beam Computed Tomography in Dentistry: What Dental Educators and Learners Should Know. J Dent Educ. 2012;76(11):1437-42.

6. Desi D, Agustina N, Adi BPS. Well-Being; Studi Sosiodemografi di Kecamatan Getasan. J Keperawatan Muhammadiyah. 2018;2(2):43-7.

7. Al Najjar A, Colosi D, Dauer LT, Prins R, Patchell G, Branets I, et al. Comparison of Adult and Child Radiation Equivalent Doses from 2 Dental Cone-Beam Computed Tomography Units. Am J Orthod Dentofac Orthop. 2013;143(6):784-92.

8. Yildizer Keriş E. Effect of Patient Anxiety on Image Motion Artefacts in CBCT. BMC Oral Health. 2017;17(73):1-9.

9. Yildizer Keris E, Demirel O, Ozdede M. Evaluation of Motion Artifacts in Cone-Beam Computed Tomography with Three Different Patient Positioning. Oral Radiol. 2021;37(2):276-81.

10. Konsil Kedokteran Indonesia. Peraturan Konsil Kedokteran Indonesia Nomor 24 tahun 2014 tentang Penerbitan Rekomendasi Pembukaan, Pembinaan, dan Penutupan Program Pendidikan Dokter Gigi Spesialis. Konsil Kedokteran Indonesia; 2014

11. Presiden Republik Indonesia. Peraturan Presiden Republik Indonesia Nomor 78 tahun 2021 tentang Badan Riset dan Inovasi Nasional. 2021.

12. Ariu M, Pasini A, Loffreda V, Toni F, Marchetti C, Battista G, et al. The Advantages of new cone-beam technology in the study of head and neck region [Internet]. 2013. Available from: www.my-ray.com

13. Misirlioglu M, Nalcaci R, Adisen MZ, Yardimci S. Bilateral and pseudobilateral tonsilloliths: Three dimensional imaging with cone-beam computed tomography. Imaging Sci Dent. 2013;43 (3):163-9.

14. Costan VV, Ciocan-Pendefunda CC, Sulea D, Popescu E, Boisteanu O. Use of Cone-Beam Computed Tomography in Performing Submandibular Sialolithotomy. J Oral Maxillofac Surg. 2019;77(8):1656.e1-1656.e8.

15. Departemen Kesehatan Republik Indonesia. Klasifikasi Umur Menurut Kategori. Jakarta: Ditjen Yankes. 2009.

16. Surti S, Candrawati E, Warsono W. Hubungan Antara Karakteristik Lanjut Usia Dengan Pemenuhan Kebutuhan Aktivitas Fisik Lansia Di Kelurahan Tlogomas Kota Malang. Nurs News J Ilm Keperawatan. 2017;2(3):103-11.

17. Data P, Informasi Kemenkes RI. Gambaran kesehatan lanjut usia di Indonesia. Bul Jendela Data dan Inf Kesehat. 2013/1-18.

18. Lativa OH, Astuti W, Mukaromah H. Aksesibilitas Fisik Puskesmas Ramah Lansia Menuju Age Friendly City Kota Yogyakarta. Desa-Kota. 3(1):1-16.

19. Triatmodjo S. Desain Interior Ramah Lansia. LINTAS RUANG J Pengetah dan Peranc Desain Inter. 2021;9(1):45-54.

20. Fabiana $\mathrm{CMH}$, Frederick SR, Jacqueline CHM. Managing Dental Patient with Auditory Deficit: Literature Review. Int J Oral Dent Heal. 2018;4:58.

21. Decree of The Director of Dental Hospital of Universitas Airlangga 488/UN3.9.3/OT/2016. Surabaya: Dental Hospital of Universitas Airlangga; 2016

22. Spin-Neto R, Matzen LH, Schropp L, Gotfredsen E, Wenzel A. Factors Affecting Patient Movement and Re-Exposure in Cone Beam Computed Tomography Examination. Oral Surg Oral Med Oral Pathol Oral Radiol. 2015;119(5):572-8.

23. Hanzelka T, Dusek J, Ocasek F, Kucera J, Sedy J, Benes J, et al. Movement Of The Patient And The Cone Beam Computed Tomography Scanner: Objectives And Possible Solutions. Oral Surg Oral Med Oral Pathol Oral Radiol. 2013;116(6):769-73.

24. Mamai-Homata $E$, Koletsi-Kounari $H$, Margaritis V. Gender Differences In Oral Health Status And Behavior Of Greek Dental Students: A Meta-Analysis Of 1981, 2000, And 2010 Data. J Int Soc Prev Community Dent. 2016;6(1):60.

25. Buunk-Werkhoven YAB, Buunk AP. Fear of Social Rejection and Oral Self-Care in Men Versus Women. Int Dent J. 2015;65:13.

26. Bhagia P, Menon I, Puri N, Arora V, Goyal J, Ashraf A. Effect Of Dental Anxiety On Motion Artefacts In CBCT Imaging Amongst Adult Patients of Muradnagar, Ghaziabad. Int J Adv Sci Technol. 2020;29(9s):2601-8.

27. Jannah M, Darmini D, Rochmayanti D. Komunikasi Efektif Berperan Dalam Meningkatkan Kepuasan Pasien Di Instalasi Radiologi. LINK. 2017;13(2):28-33. 